W hen new pests or diseases become established, they often lack the natural control of their native environments and develop into more serious problems when interacting with local plant or animal systems or local management practices. The response to constrain and manage them must be complex and coordinated between research institutions and scientists, government agencies and the agricultural community. The articles in this section profile two successful multi-partner responses to newly established threats to one of California's premier commodities.

\title{
Growers, scientists and regulators collaborate on European grapevine moth program
}

by Monica Cooper, Lucia Varela, Rhonda Smith, David Whitmer, Gregory Simmons, Andrea Lucchi, Roxanne Broadway and Robert Steinhauer

The first detection of the European grapevine moth in North America triggered the establishment of federal and state regulatory programs that (1) identified the insect's geographic range in California, (2) developed and implemented detection and management programs, (3) regulated the movement of plant material and equipment to minimize the threat of dispersal, (4) incorporated research-based information developed by subject-matter experts into policy decisions and (5) promoted a wide-reaching educational program for grape growers, the public and local officials. The action plan, developed and carried out through a coordinated program that included multiple government agencies, university scientists and the agricultural community, drastically reduced insect populations and limited the distribution in California vineyards such that some previously infested areas were removed from quarantine regulation.

$\mathrm{I}$ nvasive species increasingly threaten agricultural sustainability in a global economy. If an invasive species is a known pest or assessed as potentially threatening, its detection in California may trigger a regulatory response coordinated by the U.S. Department of Agriculture (USDA), the California Department of Food and Agriculture (CDFA) and agricultural commissioners. Regulatory programs often encompass activities such as trapping, quarantine and treatment protocols, and depend on reliable scientific information generated by university researchers. European grapevine moth, Lobesia botrana (Denis \& Schiffermüller), is endemic to Mediterranean Europe, has invaded portions of the Palearctic region (Europe, west Asia and North Africa) and East Africa, and was detected for the first time in the Americas in Chile, April 2008; in California, September 2009; and in Argentina, April 2010 (Ioriatti et al. 2012; Varela et al. 2013a). In the United States,

Online: http://californiaagriculture.ucanr.edu/ landingpage.cfm?article=ca.v068n04p125\&fulltext=yes doi: 10.3733/ca.v068n04p125 the first detections were in Napa County, California, where this invasive pest and associated fungal rot caused significant crop damage in 2009. A coordinated program by USDA, CDFA, county agricultural commissioners, UC, international caused significant crop damage. scientists and grape growers aimed to control, contain and potentially eradicate insect populations. The cooperative effort to develop and implement this program is the focus of this article.

\section{Seasonal biology in California vineyards}

The European grapevine moth (EGVM) may complete two to five annual generations, as determined by latitude, climate and microclimate (Ioriatti et al. 2011); temperature models predict three generations per year in the Napa Valley, which has been validated through ground observations (Gutierrez et al. 2012).

Pupae overwinter in diapause (a resting state) inside silken cocoons in protected locations, such as under the bark of the vine. The first male flight generally begins slightly before budbreak and may continue for 10 to 14 weeks. Adults generally fly at dusk when temperatures

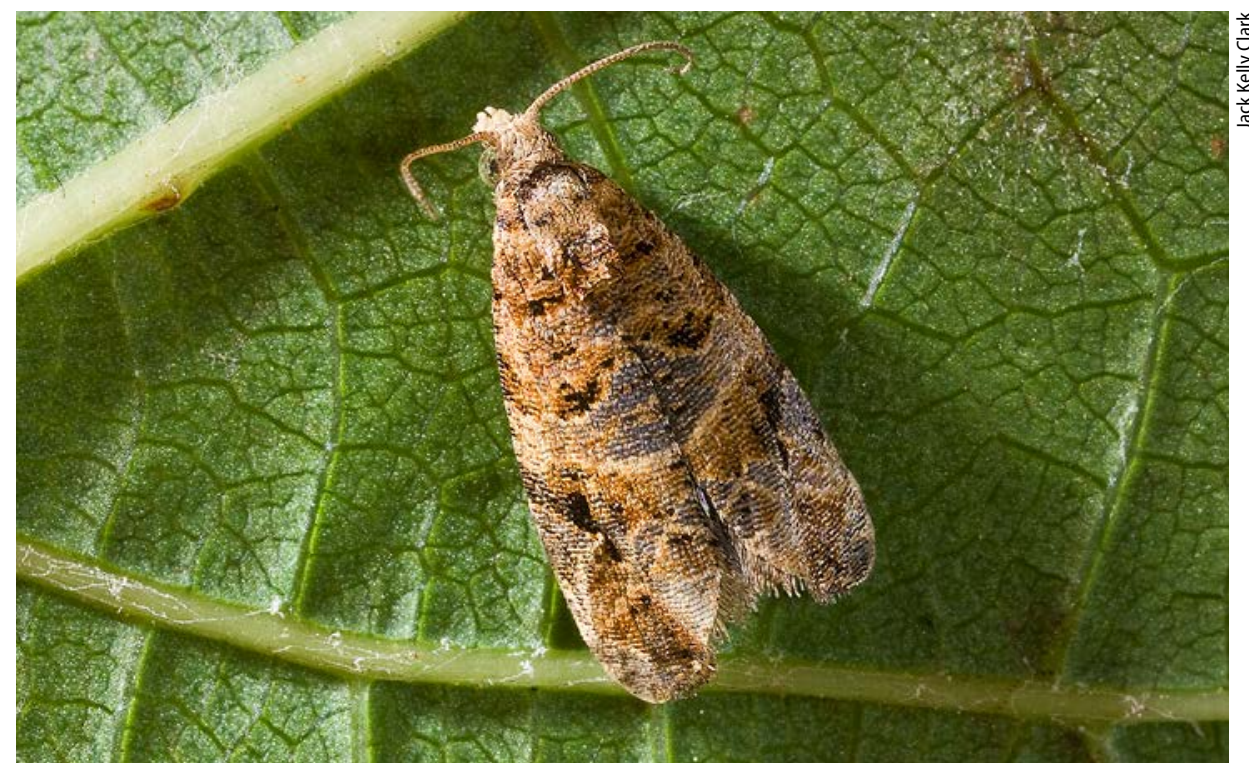

In 2009, European grapevine moth was first detected in the United States in Napa County, where it 


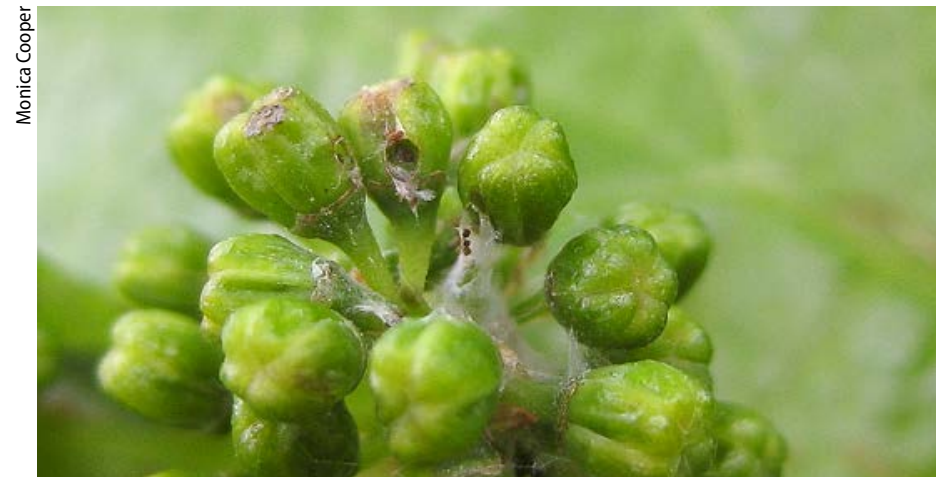

Feeding damage by European grapevine moth larva to a grape flower before bloom. Note the characteristic hole in the flower, webbing and larval excrement.

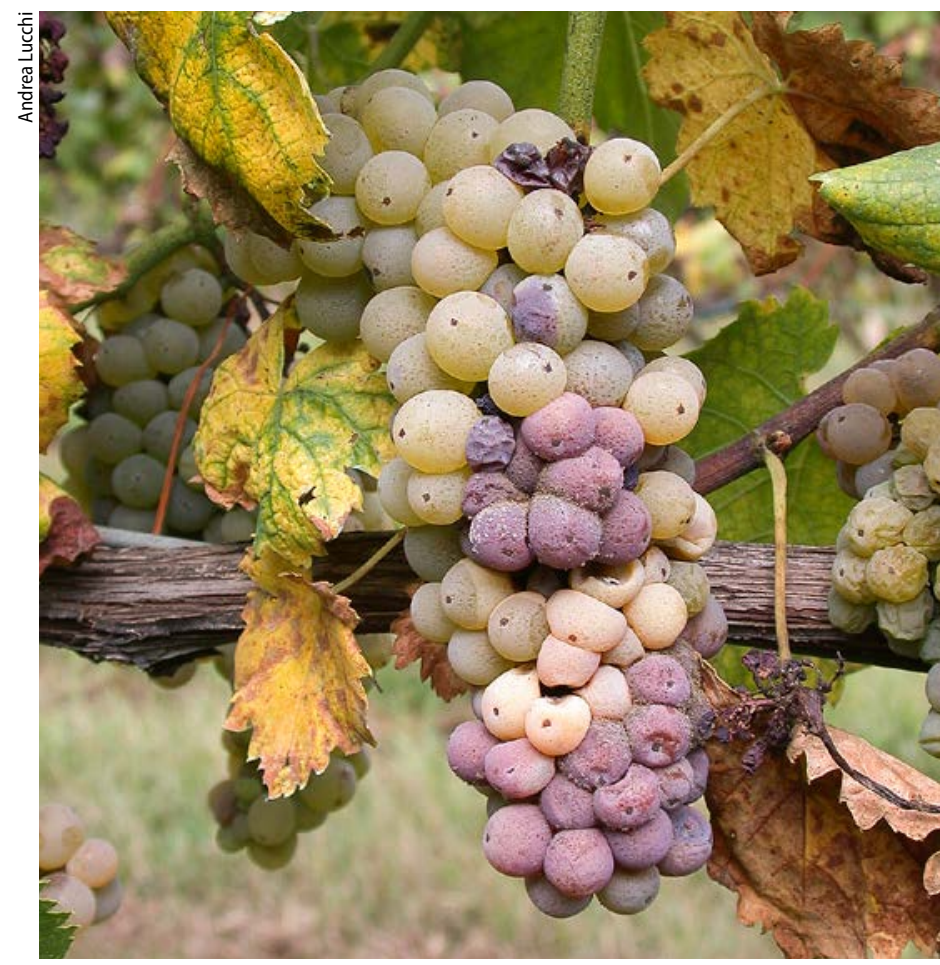

Feeding damage to grape berries by second- and third-generation larvae exposes them to fungal infections that can be economically damaging. are above $53.5^{\circ} \mathrm{F}\left(12^{\circ} \mathrm{C}\right)$. During the first flight, the female glues single eggs to flat surfaces on or near the flower cluster; secondand third-generation eggs are laid on grape berries. Larvae form webbed nests; the first-generation larvae feed on flowers before and during bloom in Northern California; second-generation larvae feed on green berries; and third-generation larvae feed inside ripening berries. Larvae create distinctive round holes in prebloom flowers and ripening fruit, which distinguishes their feeding damage from that of other common Lepidoptera larvae found in California vineyards (photo, left). Feeding damage to berries by second- and third-generation larvae exposes them to infection by Botrytis and other secondary fungi (photo, below left) that can be economically damaging.

\section{Quarantine programs}

On October 7, 2009, USDA confirmed the presence of EGVM in Napa County. A federal order issued by USDA in June 2010 initiated a quarantine area within 5 miles (8 kilometers $[\mathrm{km}])$ of all detections (USDA 2010). Detections were defined as two or more adult moths trapped within 3 miles $(5 \mathrm{~km})$ of each other during the same life cycle or immature stages confirmed to be EGVM by DNA analysis. The order indicated plant host species as well as plant parts, products, farming and processing equipment, and green waste residues as regulated articles that could not be transported interstate from a quarantine area except under specific conditions. The state interior quarantine (CDFA 2012) enforced restrictions parallel to those in the federal order for intrastate movement of regulated articles within or from quarantine areas. In 2012, the quarantine buffer was reduced from 5 miles to 3 miles $(5 \mathrm{~km})$ around detections. This change accommodated the program's need to reduce the cost of implementation while acknowledging the adult moths' short-distance natural dispersal (Boller 1993; Schmitz et al. 1996).

\section{Statewide survey and detection program}

Immediately after the first confirmed detection in 2009, USDA, CDFA and the Napa County agricultural commissioner deployed 248 sex pheromone-baited traps to delimit the population. However, very few moths were caught because traps were deployed at the end of the third flight (table 1). In addition to the trap captures, ground surveys in 2009 recorded 26 larvae, eight

TABLE 1. European grapevine moths captured in pheromone-baited traps, presented by California county and by year (2009-2014)

\begin{tabular}{|c|c|c|c|c|c|c|c|c|c|c|c|}
\hline Year & Napa & Sonoma & Solano & Mendocino & Fresno & Merced & San Joaquin & Santa Cruz & Santa Clara & Monterey & Nevada \\
\hline & . & & & & Number & moths ( $r$ & nber of traps) & & & & $\ldots \ldots$ \\
\hline 2009 & $\begin{array}{r}5 \\
(248)\end{array}$ & & & & & & & & & & \\
\hline 2010 & $\begin{array}{r}100,831 \\
(3,882)\end{array}$ & $\begin{array}{r}59 \\
(6,932)\end{array}$ & $\begin{array}{r}11 \\
(1,514)\end{array}$ & $\begin{array}{r}36 \\
(1,594)\end{array}$ & $\begin{array}{r}11 \\
(8,648)\end{array}$ & $\begin{array}{r}4 \\
(860)\end{array}$ & $\begin{array}{r}2 \\
(3,522)\end{array}$ & $\begin{array}{r}1 \\
(449)\end{array}$ & $\begin{array}{r}3 \\
(596)\end{array}$ & $\begin{array}{r}1 \\
(1,733)\end{array}$ & $\begin{array}{r}0 \\
(55)\end{array}$ \\
\hline 2011 & $\begin{array}{r}113 \\
(4,930)\end{array}$ & $\begin{array}{r}9 \\
(9,048)\end{array}$ & $\begin{array}{r}0 \\
(2,644)\end{array}$ & $\begin{array}{r}0 \\
(2,237)\end{array}$ & $\begin{array}{r}0 \\
(11,013)\end{array}$ & $\begin{array}{r}0 \\
(1,502)\end{array}$ & $\begin{array}{r}0 \\
(7,537)\end{array}$ & $\begin{array}{r}1 \\
(552)\end{array}$ & $\begin{array}{r}19 \\
(1,346)\end{array}$ & $\begin{array}{r}0 \\
(2,651)\end{array}$ & $\begin{array}{r}4 \\
(1,902)\end{array}$ \\
\hline 2012 & $\begin{array}{r}77 \\
(4,706)\end{array}$ & $\begin{array}{r}0 \\
(8,393)\end{array}$ & $\begin{array}{r}0 \\
(1,844)\end{array}$ & $\begin{array}{r}0 \\
(1,432)\end{array}$ & $\begin{array}{r}0 \\
(8,630)\end{array}$ & $\begin{array}{r}0 \\
(86)\end{array}$ & $\begin{array}{r}0 \\
(4,714)\end{array}$ & $\begin{array}{r}0 \\
(318)\end{array}$ & $\begin{array}{r}0 \\
(658)\end{array}$ & $\begin{array}{r}0 \\
(2,033)\end{array}$ & $\begin{array}{r}0 \\
(920)\end{array}$ \\
\hline 2013 & $\begin{array}{r}40 \\
(11,621)\end{array}$ & $\begin{array}{r}0 \\
(6,906)\end{array}$ & $\begin{array}{r}0 \\
(1,383)\end{array}$ & $\begin{array}{r}0 \\
(1,430)\end{array}$ & $\begin{array}{r}0 \\
(7,651)\end{array}$ & $\begin{array}{r}0 \\
(1,265)\end{array}$ & $\begin{array}{r}0 \\
(1,301)\end{array}$ & $\begin{array}{r}0 \\
(202)\end{array}$ & $\begin{array}{r}0 \\
(267)\end{array}$ & $\begin{array}{r}0 \\
(1,998)\end{array}$ & $\begin{array}{r}0 \\
(60)\end{array}$ \\
\hline $2014^{*}$ & $\begin{array}{r}0 \\
(11,574) \\
\end{array}$ & $\begin{array}{r}1 \\
(7,011) \\
\end{array}$ & $\begin{array}{r}0 \\
\text { (ND) } \\
\end{array}$ & $\begin{array}{r}0 \\
(1,468) \\
\end{array}$ & $\begin{array}{r}0 \\
(2,169) \\
\end{array}$ & $\begin{array}{r}0 \\
(828) \\
\end{array}$ & $\begin{array}{r}0 \\
(4,243) \\
\end{array}$ & $\begin{array}{r}0 \\
\text { (ND) } \\
\end{array}$ & $\begin{array}{r}0 \\
\text { (ND) } \\
\end{array}$ & $\begin{array}{r}0 \\
(1,978) \\
\end{array}$ & $\begin{array}{r}0 \\
\text { (ND) } \\
\end{array}$ \\
\hline
\end{tabular}

* These are preliminary values, as of July 30, 2014; final values will be available in November 2014; ND = no preliminary data available. 
pupae and one female at multiple sites in two distinct areas of Napa County. As a result, the state interior quarantine was established in March 2010, over an area totaling 162 square miles (420 square kilometers $\left[\mathrm{km}^{2}\right]$ ) in Napa County (fig. 1).

In February 2010, trapping efforts expanded throughout all grape-growing regions of California — roughly 803,000 acres $(325,000$ hectares [ha]). Traps were deployed at densities of nine to 16 or 25 traps per square mile of planted vineyard (three to six or 10 traps per $\mathrm{km}^{2}$ ) outside and inside the regulated area, respectively (table 1). In select urban areas, traps were placed on potential EGVM host plants at a density of five traps per square mile (two traps per $\mathrm{km}^{2}$ ) (Mastro et al. 2010). By the end of 2010, the quarantine area included portions of eight California counties, totaled 2,091 square miles $\left(5,416 \mathrm{~km}^{2}\right)$ and contained approximately 150,760 acres $(61,010 \mathrm{ha})$ of vineyards (fig. 2, table 2). Subsequently, in 2011, traps detected moths in two additional counties, bringing the total number of regulated counties to 10 and a peak quarantine area of 2,335 square miles $\left(6,048 \mathrm{~km}^{2}\right)$ (fig. 2, table 2). Trap captures in Napa County indicated a large, widely distributed population, whereas populations in other counties were significantly smaller and more contained (table 1).

The EGVM regulatory program has relied heavily on the use of pheromonebaited sticky traps to detect moth populations. UC scientists evaluated the efficacy and longevity of four pheromone lures in replicated field experiments in Napa during the first and second moth flights of 2010 (Varela et al. 2013b). All lures were

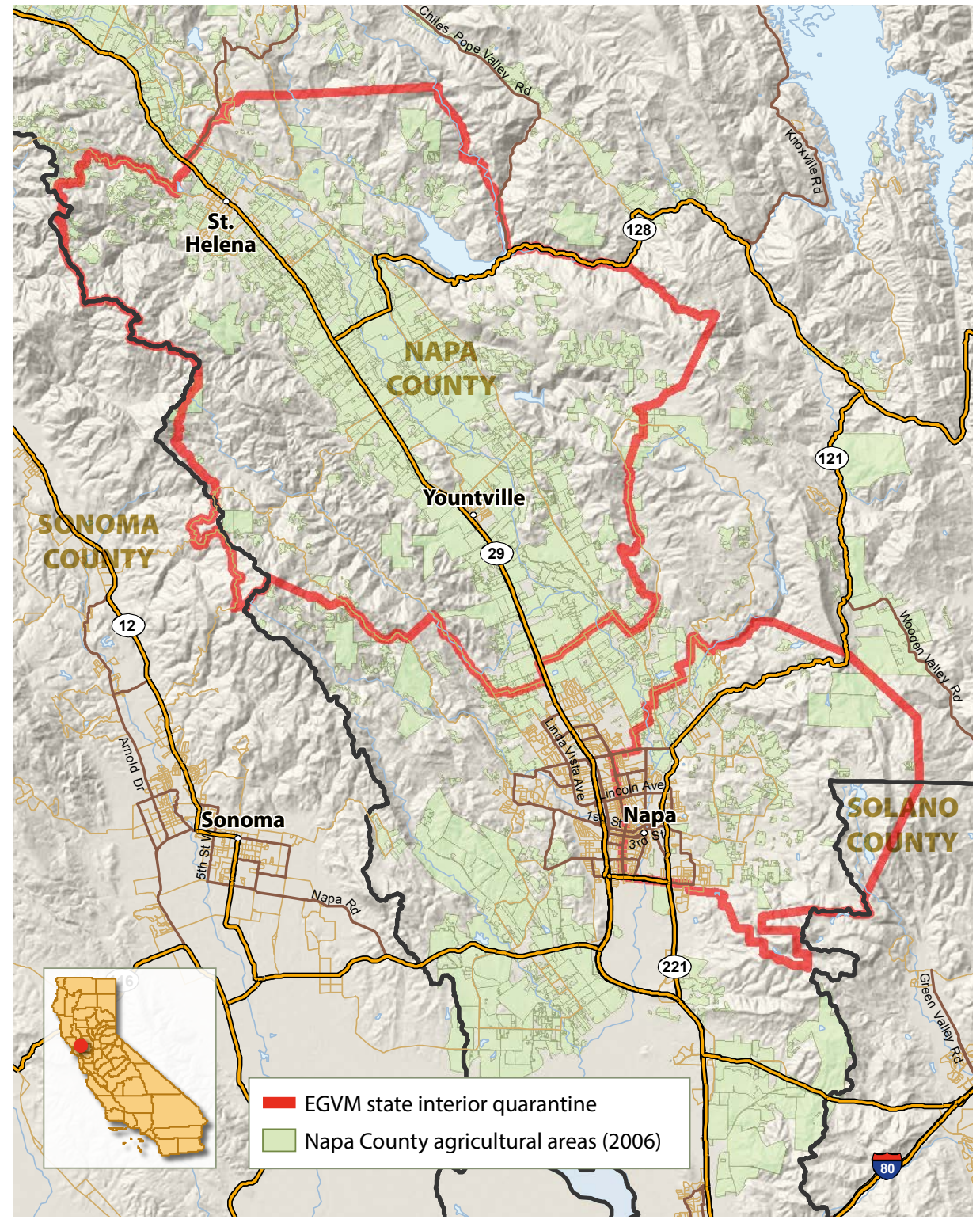

Fig. 1. The state interior quarantine established in Napa County, California, following the first detection of EGVM (September 29,2009$)$ in North America. The area encompassed all areas within a 5 -mile $(8 \mathrm{~km})$ radius of all known EGVM populations at that time, as determined by trap captures and ground surveys.

TABLE 2. Quarantine area in square miles (vineyard acres inside quarantine) by county and year

\begin{tabular}{|c|c|c|c|c|c|c|c|c|c|c|c|}
\hline Year & Napa & Sonoma & Solano & Mendocino & Fresno & Merced & $\begin{array}{c}\text { San } \\
\text { Joaquin }\end{array}$ & Santa Cruz & Santa Clara & Nevada & California total \\
\hline & $\cdots$ & & & & ..Squ & miles (vine & d acres).... & …....... & & & $\cdots$ \\
\hline 2010 & $\begin{array}{r}597 \\
(43,139)\end{array}$ & $\begin{array}{r}664 \\
(52,000)\end{array}$ & $\begin{array}{r}237 \\
(2,397)\end{array}$ & $\begin{array}{r}179 \\
(5,860)\end{array}$ & $\begin{array}{r}96 \\
(24,769)\end{array}$ & $\begin{array}{r}108 \\
(1,432)\end{array}$ & $\begin{array}{r}96 \\
(20,544)\end{array}$ & $\begin{array}{r}0 \\
(0)\end{array}$ & $\begin{array}{r}94 \\
(619)\end{array}$ & $\begin{array}{r}0 \\
(0)\end{array}$ & $\begin{array}{r}2,091 \\
(150,760)\end{array}$ \\
\hline 2011 & $\begin{array}{r}597 \\
(43,452)\end{array}$ & $\begin{array}{r}664 \\
(52,000)\end{array}$ & $\begin{array}{r}237 \\
(2,397)\end{array}$ & $\begin{array}{r}179 \\
(5,860)\end{array}$ & $\begin{array}{r}96 \\
(24,769)\end{array}$ & $\begin{array}{r}108 \\
(1,432)\end{array}$ & $\begin{array}{r}96 \\
(20,544)\end{array}$ & $\begin{array}{r}87 \\
(310)\end{array}$ & $\begin{array}{r}94 \\
(619)\end{array}$ & $\begin{array}{r}176 \\
(345)\end{array}$ & $\begin{array}{r}2,335 \\
(151,728)\end{array}$ \\
\hline 2012 & $\begin{array}{r}575 \\
(43,078)\end{array}$ & $\begin{array}{r}458 \\
(46,500)\end{array}$ & $\begin{array}{r}124 \\
(2,289)\end{array}$ & \multirow{3}{*}{\multicolumn{2}{|c|}{ Removed from }} & & & $\begin{array}{r}34 \\
(231)\end{array}$ & $\begin{array}{r}38 \\
(552)\end{array}$ & $\begin{array}{r}74 \\
(99)\end{array}$ & $\begin{array}{r}1,302 \\
(92,749)\end{array}$ \\
\hline 2013 & $\begin{array}{r}554 \\
(42,703)\end{array}$ & $\begin{array}{r}78^{*} \\
(5,600)\end{array}$ & $\begin{array}{r}55^{\dagger} \\
(1,009)\end{array}$ & & & antine $3 / \varepsilon$ & 12 & \multirow{2}{*}{\multicolumn{3}{|c|}{$\begin{array}{l}\text { Removed from quarantine } \\
\qquad 12 / 21 / 2012\end{array}$}} & $\begin{array}{r}687 \\
(49,312)\end{array}$ \\
\hline 2014 & $\begin{array}{r}554 \\
(42,703)\end{array}$ & $\begin{array}{r}78 \\
(5,600)\end{array}$ & $\begin{array}{r}55 \\
(1,009) \\
\end{array}$ & & & & & & & & $\begin{array}{r}687 \neq \\
(49,312)\end{array}$ \\
\hline
\end{tabular}

* In Sonoma County, 380 square miles were removed from quarantine on 12/21/2012.

† In Solano County, 69 square miles were removed from quarantine on 8/24/2012.

₹ Effective August 2014: the quarantine area measures 446 square miles, following the removal of Solano County and portions of Napa and Sonoma counties. 


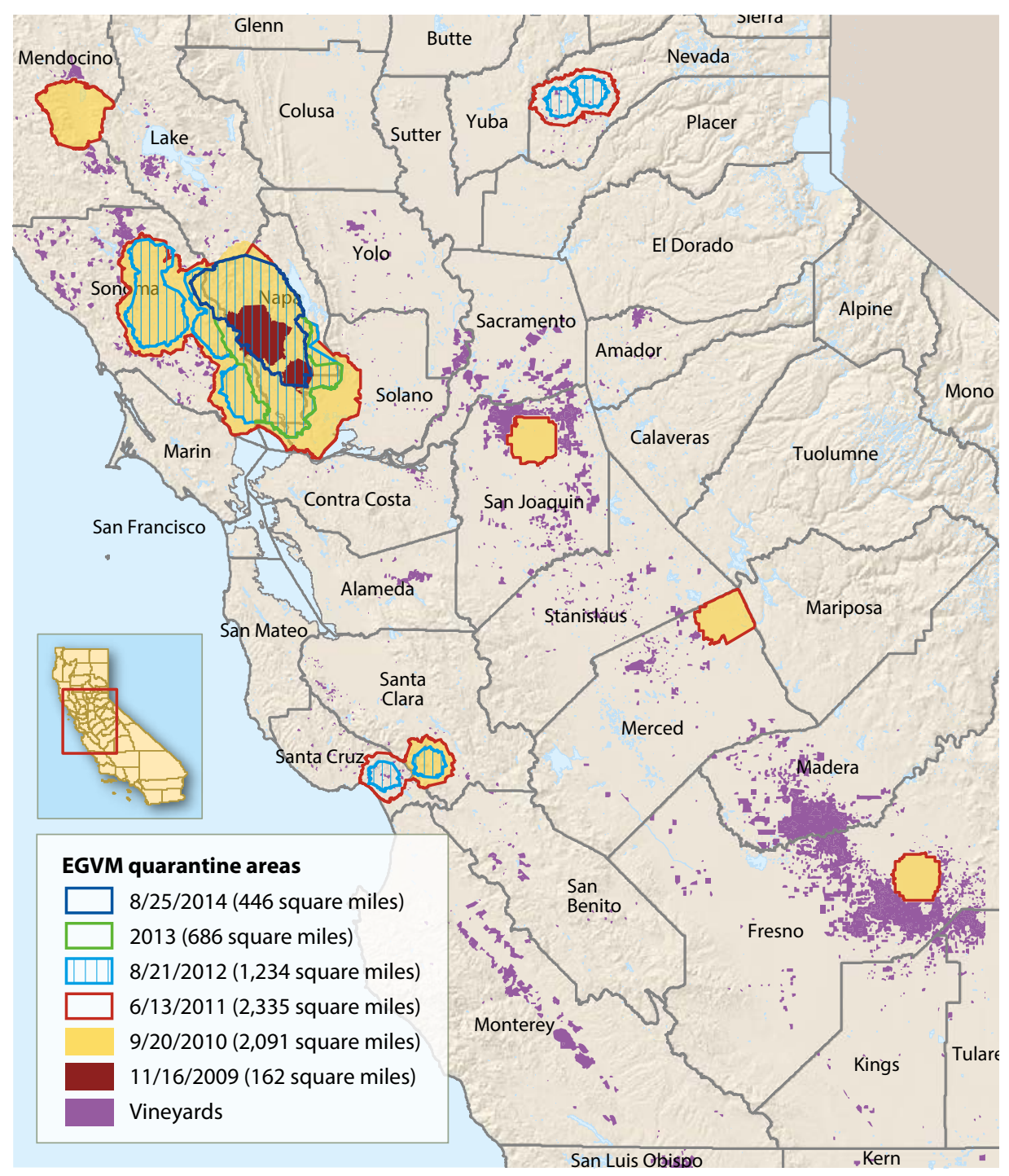

Fig. 2. Regulated areas of California for EGVM, defined by USDA, 2009 to 2014.

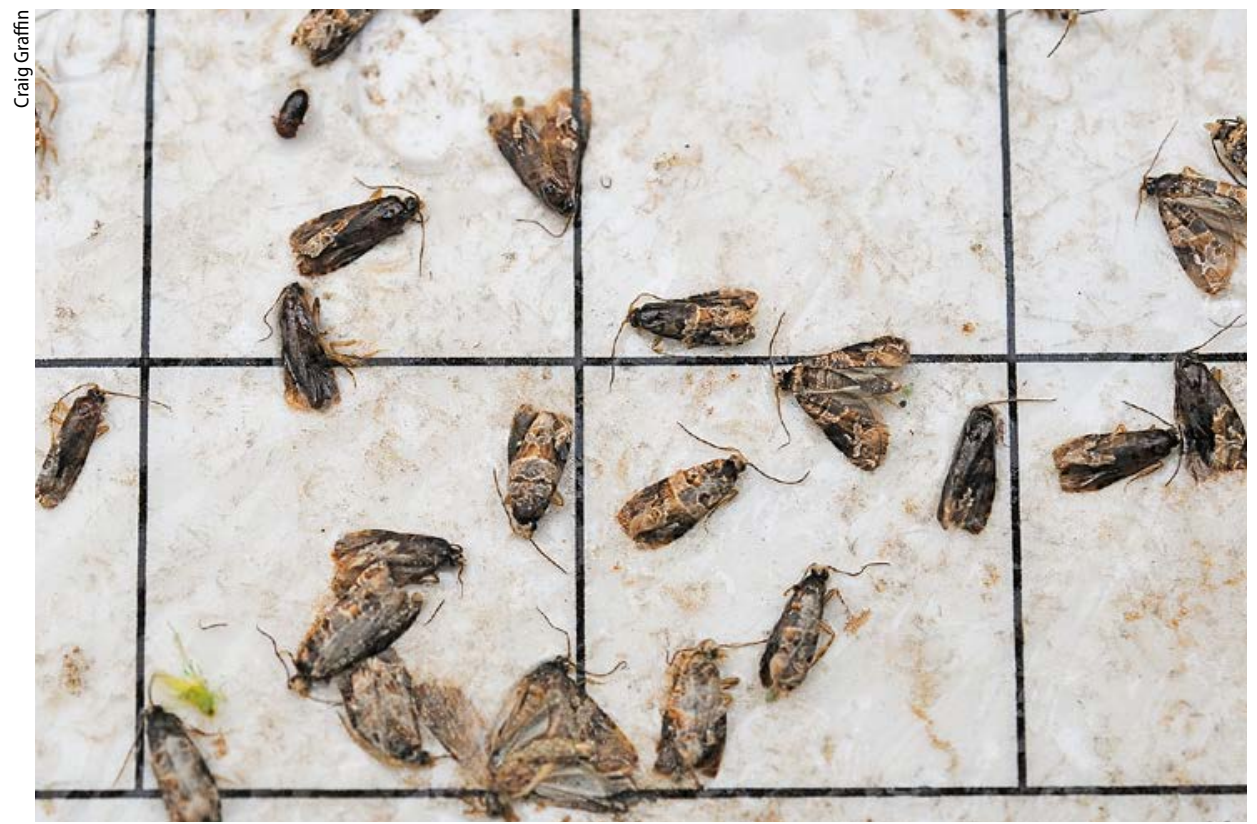

The distinctive color pattern on EGVM wings make them easily recognizable in pheromone-baited traps. effective for monitoring EGVM male moth populations during and beyond the period recommended by the manufacturer (fig. 3).

\section{International technical working group}

In November 2009, USDA assembled a technical working group (TWG) of subject-matter experts to provide urgent scientific recommendations to regulatory program managers in California. The TWG included university scientists from Italy, France, Germany, Spain, Chile and California, as well as USDA scientists (and chair) and a representative of the wine grape industry. TWG members continue to meet annually to review program activities and provide technical expertise on topics as diverse as insect biology, detection strategies, handling of harvested fruit and winery waste, and management activities.

Since 2010, TWG members have agreed that eradication of EGVM from California remains a realistic goal as long as (1) the population did not become substantially more widespread than was known at that time, (2) the grape industry remained supportive of the effort and (3) effective control methods were available for use by the program (Mastro et al. 2010). Over the course of the EGVM program, TWG members evaluated research data and program developments to formulate recommendations based on the insect's biology. Government agencies matched these recommendations to political and fiscal analyses to formulate and deliver the EGVM program.

\section{Management tools}

Treatment areas. Treatment areas were defined within a requisite distance from all detections and included agricultural, residential and commercial properties. In 2010, the distance was not standardized, so the size of the treatment areas varied by county. Following a review of the scientific literature suggesting that EGVM are short-distance fliers, the TWG recommended a treatment area within 1,640 feet (500 meters [m]) of all detections regardless of when the detection occurred. From 2013 onward, the TWG modified this recommendation to account for timing of the detection: Treatment areas came to be defined as within $500 \mathrm{~m}$ of detections occurring in the current year and previous 2 years. Within the treatment areas, 
grape and olive were the targeted hosts of concern, and total vineyard acreage varied considerably by county and year (table 3). The specific combination of tools (insecticides, mating disruption and host removal) used in treatment areas differed by land use and occurrence of potential host plant species.

Insecticide program. The recommended insecticide program for EGVM in California vineyards targets the eggs and larvae and includes at least one application of a conventional insecticide or at least two applications of an organic insecticide for each of the first two generations (and for the third generation in extenuating circumstances). Although treatment of the first generation is not typical in the Palearctic regions, the TWG determined that treating the first two generations in California would provide the greatest opportunity to eradicate populations. In early 2010, UC scientists provided an exhaustive list of potential insecticides for EGVM management based on a review of the scientific literature. From this list, EGVM program leaders made a concerted effort to identify and recommend products that would provide selective control of EGVM while minimizing risks to nontarget organisms and the environment.

The availability of organic treatment options ensured that growers could maintain organic certification while complying with the eradication effort. Pesticide use reporting (PUR) data for Napa County (2010 to 2014) indicate that growers used a combination of the recommended materials (table 4).

Insecticide efficacy trials. UC scientists conducted field trials in commercial vineyards in Napa in 2010 to evaluate the efficacy of registered insecticides for EGVM.

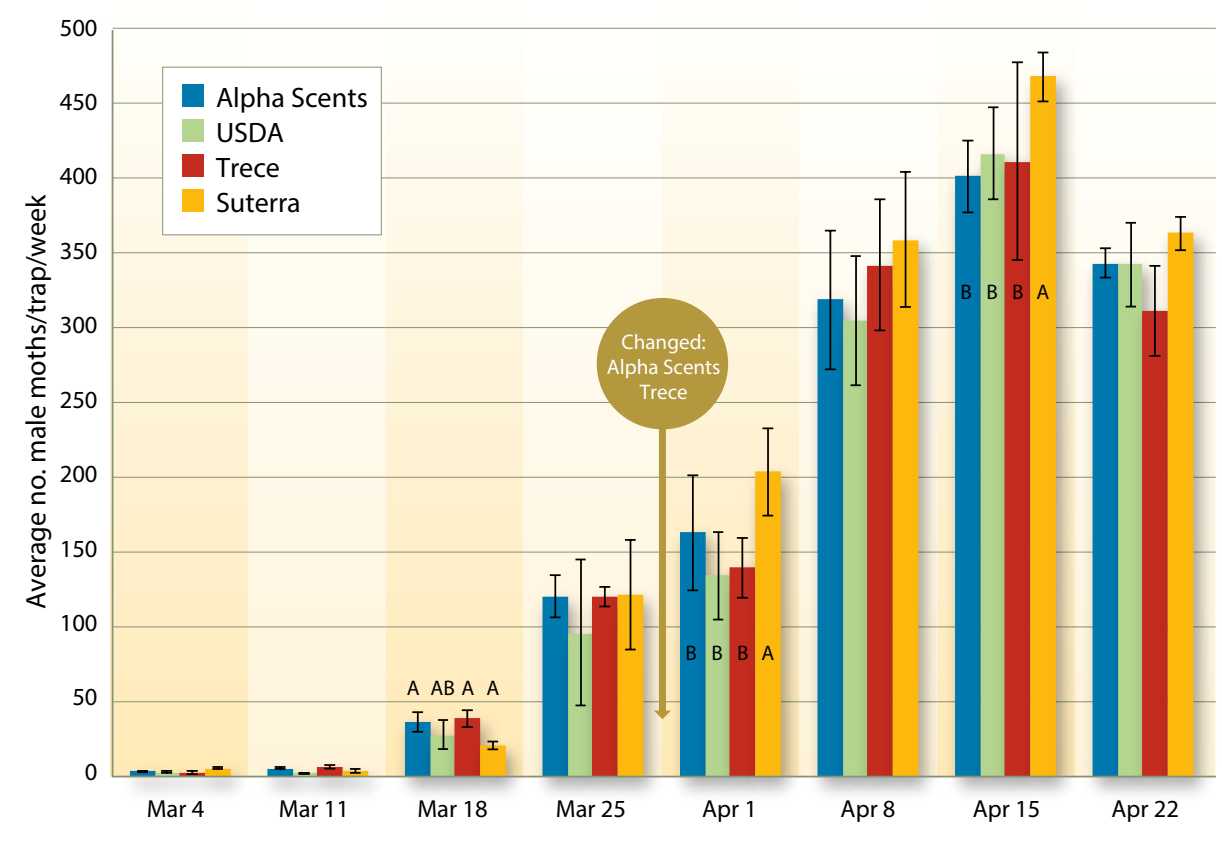

Fig. 3. Average number of male moths caught in traps baited with commercial pheromone lures and a USDA lure monitored from February 25 to April 22, 2010. Alpha Scents, USDA and Trece lures are rubber septa, and Suterra is a membrane lure. Letters indicate homogenous groups at $95 \%$ least significant difference. Per the manufacturer's recommendation, the Alpha Scents and Trece lures were changed 4 weeks into the experiment.

Chlorantraniliprole, methoxyfenozide, spinosad and Bacillus thuringiensis provided control of young larvae; abamectin, indoxacarb and spinetoram provided the best control of mature larvae (Van Steenwyk et al. 2011). These results were widely distributed to the program team and grape growers.

Insecticide treatment. Selective insecticides are most effective if applied when the pest is at its most susceptible stage (Ioriatti et al. 2011). In Napa County, UC scientists monitored the male flight, egg and larva development and calculated degree-days (lower and upper thresholds of $50^{\circ} \mathrm{F}$ and $86^{\circ} \mathrm{F}$ [ $\left[10^{\circ} \mathrm{C}\right.$ and $30^{\circ} \mathrm{C}$, respectively) from a biofix of January 1 for each life stage (Caffarelli and Vita 1988; Touzeau 1981). Referencing these observations and calculations to local weather data and vine phenology, UC scientists then determined the optimal timing for insecticide applications for all affected locations in California. For each generation, a 3-week treatment window minimized application costs by combining the insecticide with preventative treatments for powdery mildew. This information was widely disseminated via conference calls with government agencies, a UC electronic newsletter, industry associations' e-news blasts, and grower liaisons in Napa, Sonoma, Fresno and Mendocino counties. An analysis of the PUR data

TABLE 3. Insecticide-treated acres and reported use of Isomate EGVM pheromone dispensers in counties affected by quarantine regulations

\begin{tabular}{|c|c|c|c|c|c|c|c|c|c|c|}
\hline Year & Napa & Sonoma & Solano & Mendocino & Fresno & Merced & San Joaquin & Santa Cruz & Santa Clara & Nevada \\
\hline $2010^{*}$ & & $\begin{array}{r}\sim 8,000 \\
(0)\end{array}$ & $\begin{array}{r}594 \\
(0)\end{array}$ & $\begin{array}{r}94 \\
(13)\end{array}$ & $\begin{array}{r}928 \\
(0)\end{array}$ & $\begin{array}{r}620 \\
(0)\end{array}$ & $\begin{array}{r}364 \\
(0)\end{array}$ & $\mathrm{N} / \mathrm{A}$ & $\mathrm{N} / \mathrm{A}$ & $\mathrm{N} / \mathrm{A}$ \\
\hline $2011 \dagger$ & $\begin{array}{r}23,700 \\
(13,300)\end{array}$ & $\begin{array}{r}2,395 \\
(1,533)\end{array}$ & $\begin{array}{r}785 \\
(0)\end{array}$ & $\begin{array}{r}201 \\
(100)\end{array}$ & $\begin{array}{r}540 \\
(0)\end{array}$ & $\begin{array}{r}200 \\
(0)\end{array}$ & $\begin{array}{l}83 \\
(0)\end{array}$ & $\begin{array}{l}16 \\
(0)\end{array}$ & $\begin{array}{r}114 \\
(0)\end{array}$ & $\begin{array}{r}8 \\
(8)\end{array}$ \\
\hline $2012 \neq$ & $\begin{array}{r}28,000 \\
(23,071)\end{array}$ & $\begin{array}{r}2,395 \\
(0)\end{array}$ & $\mathrm{N} / \mathrm{A}$ & $\mathrm{N} / \mathrm{A}$ & $\mathrm{N} / \mathrm{A}$ & $\mathrm{N} / \mathrm{A}$ & $\mathrm{N} / \mathrm{A}$ & $\begin{array}{l}16 \\
(0)\end{array}$ & $\begin{array}{r}114 \\
(0)\end{array}$ & $\begin{array}{r}8 \\
(0)\end{array}$ \\
\hline $2013 \S$ & $\begin{array}{l}11,800 \\
(2,800)\end{array}$ & $\begin{array}{l}23 \\
(0)\end{array}$ & $\mathrm{N} / \mathrm{A}$ & $\mathrm{N} / \mathrm{A}$ & N/A & $\mathrm{N} / \mathrm{A}$ & $\mathrm{N} / \mathrm{A}$ & $\mathrm{N} / \mathrm{A}$ & $\mathrm{N} / \mathrm{A}$ & N/A \\
\hline
\end{tabular}

* Treatment areas are within 1,000 $\mathrm{m}$ of any detection in 2010 (except Napa and Solano [200 m]).

† Treatment areas are within $500 \mathrm{~m}$ of any detection in 2010 or 2011.

₹ Treatment areas are within $500 \mathrm{~m}$ of any detection in 2010, 2011 or 2012.

§ Treatment acres are within $500 \mathrm{~m}$ of any detection in 2011, 2012 or 2013. 
from 2011 and 2012 shows a high level of compliance for treatment timing among Napa County growers (table 5).

Mating disruption. Mating disruption (MD) programs deploy synthetic $(E, Z)$ 7,9-dodecadienyl acetate - the main component of the female sex pheromone — in hand-applied dispensers (Pasquier and Charmillot 2005). When applied as an area-wide control strategy in Palearctic regions, MD has provided sustained control of EGVM populations while decreasing reliance on insecticides and reducing conflict between agricultural and urban populations (Ioriatti et al. 2011). Although MD does not completely inhibit EGVM mating, delayed mating reduces populations because older females produce fewer eggs than younger females (TorresVila et al. 2002). TWG scientists strongly

TABLE 4. Pesticide use report data collected by the Napa County agricultural commissioner for applications targeting EGVM during the first and second generations of 2011 and 2012 within defined treatment areas (all vineyards within $500 \mathrm{~m}$ of all EGVM detections)

\begin{tabular}{|c|c|c|c|c|c|c|}
\hline $\begin{array}{l}\text { First } \\
\text { generation }\end{array}$ & $\begin{array}{c}\text { Second } \\
\text { generation }\end{array}$ & Year & Acres treated & $\begin{array}{l}\text { Percent of } \\
\text { total acres }\end{array}$ & Sites treated & $\begin{array}{l}\text { Percent of } \\
\text { total sites }\end{array}$ \\
\hline \multirow[t]{2}{*}{ Conventional } & \multirow[t]{2}{*}{ Conventional } & 2011 & 11,111 & 46.9 & 593 & 48.4 \\
\hline & & 2012 & 11,597 & 60.9 & 444 & 52.5 \\
\hline \multirow[t]{2}{*}{ Organic } & \multirow[t]{2}{*}{ Organic } & 2011 & 2,073 & 8.7 & 113 & 9.2 \\
\hline & & 2012 & 2,492 & 13.0 & 115 & 14.0 \\
\hline \multirow{2}{*}{$\begin{array}{l}\text { Conventional } \\
\text { or organic }\end{array}$} & \multirow{2}{*}{$\begin{array}{c}\text { Conventional } \\
\text { or organic }\end{array}$} & 2011 & 41 & 0.17 & 4 & 0.33 \\
\hline & & 2012 & 195 & 1.0 & 15 & 1.8 \\
\hline \multirow[t]{2}{*}{ Insecticide } & \multirow[t]{2}{*}{ None } & 2011 & 5,290 & 22.3 & 194 & 15.8 \\
\hline & & 2012 & 1,063 & 5.6 & 83 & 9.8 \\
\hline \multirow[t]{2}{*}{ None } & \multirow[t]{2}{*}{ Insecticide } & 2011 & 1,783 & 7.5 & 73 & 6.0 \\
\hline & & 2012 & 814 & 4.3 & 51 & 6.0 \\
\hline \multirow[t]{2}{*}{ None } & \multirow[t]{2}{*}{ None } & 2011 & 3,399 & 14.3 & 249 & 20.3 \\
\hline & & 2012 & 2,869 & 15.1 & 138 & 16.3 \\
\hline
\end{tabular}

Conventional insecticides: abamectin, chlorantraniliprole, and methoxyfenozide; organic insecticides: spinosad and Bacillus thuringiensis. "None" indicates that no insecticide targeting EGVM was reported.

TABLE 5. Timing of reported insecticide treatments in Napa County targeting the first and second generations of 2011 and 2012 categorized as: recommended timing, before or after

\begin{tabular}{|c|c|c|c|c|c|c|c|}
\hline \multirow[b]{2}{*}{ Product } & \multirow[b]{2}{*}{ Year } & \multicolumn{3}{|c|}{$\begin{array}{l}\text { Acres treated, by treatment timing } \\
\text { for first generation } \\
\text { (percent of total) }\end{array}$} & \multicolumn{3}{|c|}{$\begin{array}{l}\text { Acres treated, by treatment timing } \\
\text { for second generation } \\
\text { (percent of total) }\end{array}$} \\
\hline & & Before & Recommended & After & Before & Recommended & After \\
\hline \multirow[t]{2}{*}{$\begin{array}{l}\text { Chlorantraniliprole } \\
\text { (Altacor) }\end{array}$} & 2011 & - & $\begin{array}{l}444 \\
(87)\end{array}$ & $\begin{array}{r}65 \\
(13)\end{array}$ & $\begin{array}{r}1,109 \\
(10)\end{array}$ & $\begin{array}{r}9,639 \\
(89)\end{array}$ & $\begin{array}{l}68 \\
(1)\end{array}$ \\
\hline & 2012 & - & $\begin{array}{r}2,803 \\
(91)\end{array}$ & $\begin{array}{r}286 \\
(9)\end{array}$ & $\begin{array}{l}989 \\
(11)\end{array}$ & $\begin{array}{r}6,254 \\
(67)\end{array}$ & $\begin{array}{r}2,072 \\
(22)\end{array}$ \\
\hline \multirow[t]{2}{*}{$\begin{array}{l}\text { Methoxyfenozide } \\
\text { (Intrepid) }\end{array}$} & 2011 & $\begin{array}{r}3 \\
(<1)\end{array}$ & $\begin{array}{r}13,085 \\
(90)\end{array}$ & $\begin{array}{r}1,558 \\
(10)\end{array}$ & $\begin{array}{l}165 \\
(10)\end{array}$ & $\begin{array}{r}1,432 \\
(89)\end{array}$ & $\begin{array}{r}7 \\
(<1)\end{array}$ \\
\hline & 2012 & $\begin{array}{r}299 \\
(2)\end{array}$ & $\begin{array}{r}11,771 \\
(86)\end{array}$ & $\begin{array}{r}1,606 \\
(12)\end{array}$ & $\begin{array}{r}181 \\
(4)\end{array}$ & $\begin{array}{r}2,853 \\
(63)\end{array}$ & $\begin{array}{r}1,509 \\
(33)\end{array}$ \\
\hline \multirow{2}{*}{$\begin{array}{l}\text { Bacillus } \\
\text { thuringiensis } \\
\text { and/or spinosad }\end{array}$} & 2011 & $\begin{array}{r}0.3 \\
(<1)\end{array}$ & $\begin{array}{r}2,752 \\
(93)\end{array}$ & $\begin{array}{r}195 \\
(7)\end{array}$ & $\begin{array}{l}225 \\
(10)\end{array}$ & $\begin{array}{r}1,968 \\
(88)\end{array}$ & $\begin{array}{l}35 \\
(2)\end{array}$ \\
\hline & 2012 & $\begin{array}{r}210 \\
(6)\end{array}$ & $\begin{array}{r}3,146 \\
(85)\end{array}$ & $\begin{array}{r}346 \\
(9)\end{array}$ & $\begin{array}{l}745 \\
(22)\end{array}$ & $\begin{array}{r}2,464 \\
(73)\end{array}$ & $\begin{array}{r}152 \\
(5)\end{array}$ \\
\hline \multirow[t]{2}{*}{$\begin{array}{l}\text { Abamectin } \\
\text { (Agri-Mek) }\end{array}$} & 2011 & - & $\begin{array}{r}66 \\
(89)\end{array}$ & $\begin{array}{r}8 \\
(11)\end{array}$ & - & $\begin{array}{r}324 \\
(100)\end{array}$ & - \\
\hline & 2012 & $\begin{array}{l}12 \\
(9)\end{array}$ & $\begin{array}{l}110 \\
(91)\end{array}$ & - & $\begin{array}{r}16 \\
(41)\end{array}$ & $\begin{array}{r}23 \\
(59)\end{array}$ & - \\
\hline \multirow[t]{2}{*}{ Flubendiamide } & 2011 & - & - & - & - & - & - \\
\hline & 2012 & - & - & $\begin{array}{r}91 \\
(14)\end{array}$ & $\begin{array}{l}540 \\
(86)\end{array}$ & - & - \\
\hline
\end{tabular}

supported the use of MD as a control tool (Ioriatti et al. 2004; Lucchi et al. 2012), and by the second EGVM flight of 2010, Isomate EGVM pheromone dispensers (Pacific Biocontrol, Vancouver, WA) became widely used (table 3 ).

After the MD and insecticide programs were implemented, trap catches and visual inspections revealed dramatic decreases in population size in Napa County (table 1). Beginning in 2012, all Napa County vineyards within the defined treatment areas received pheromone dispensers through federal, state and local funding programs. Because MD limits the reliability of sex pheromone-baited traps and makes it very difficult to detect residual populations, the EGVM program has avoided the use of MD in treatment areas as they transition to deregulation.

Urban and residential treatment programs. CDFA personnel used multiple strategies to manage EGVM populations in noncommercial grapevines in urban and residential areas. The organic product B. thuringiensis was applied during the first and second generations if the crop was to be harvested; if not, flower and/or fruit clusters were removed in the spring or early summer (table 6). MD was also used in certain areas and select counties.

\section{Alternate host surveys}

Polyphagy by EGVM has been documented in the literature: Larvae may feed on up to 40 hosts in 27 plant families (Ioriatti et al. 2011; Lucchi and Santini 2011). However, larvae are rarely found on hosts other than Daphne gnidium and Vitis; exceptions seem to result from adaptations to local climate and flora (Ioriatti et al. 2011) or elevated pest pressure and presence of ripe fruit (Maher 2002). UC and USDA personnel used pheromonebaited traps and visual surveys to monitor a variety of plant species in Napa County that are reported to be EGVM hosts (table 7); no EGVM life stages were found during these surveys, suggesting that these species currently pose little risk in California. In separate surveys of olive orchards, 10 eggs and 12 EGVM larvae were found, indicating that olive flowers were a minor host in Napa during the first EGVM generation, but olive fruit did not host the second or third generations. The main host of consequence in California continues to be cultivated grape, Vitis vinifera. 
TABLE 6. Treatments for EGVM in noncommercial grapevines in urban areas included flower/fruit removal, applications of Bacillus thuringiensis (Bt) and mating disruption (MD)

\begin{tabular}{|c|c|c|c|c|c|c|c|c|c|c|c|}
\hline \multirow[b]{2}{*}{ Year } & \multirow[b]{2}{*}{ Treatment } & \multicolumn{10}{|c|}{ Number of properties by California county } \\
\hline & & Fresno & Mendocino & Merced & Napa & Nevada & San Joaquin & Santa Clara & Santa Cruz & Solano & Sonoma \\
\hline \multirow[t]{2}{*}{2010} & Fruit removal & 24 & 168 & 1 & & & 7 & & & 115 & \\
\hline & $\mathrm{Bt}$ & 2 & & 1 & & & 1 & & & & \\
\hline \multirow[t]{3}{*}{2011} & Fruit removal & 23 & 148 & 1 & 189 & & 1 & 9 & 14 & 306 & 165 \\
\hline & Bt & 7 & 42 & 1 & & & 12 & 13 & 4 & 63 & 34 \\
\hline & MD & & & & 2,651 & 601 & & & & & \\
\hline \multirow[t]{3}{*}{2012} & Fruit removal & & & & & 112 & & 8 & 11 & 294 & 200 \\
\hline & $\mathrm{Bt}$ & & & & & 36 & & 14 & 6 & 75 & 147 \\
\hline & $M D$ & & & & 860 & & & & & & \\
\hline \multirow[t]{3}{*}{2013} & Fruit removal & & & & 157 & & & & & & \\
\hline & $\mathrm{Bt}$ & & & & 121 & & & & & & \\
\hline & $M D$ & & & & 373 & & & & & & \\
\hline
\end{tabular}

\section{Compliance agreements}

To prevent the movement of EGVM on regulated articles grown inside quarantine areas, CDFA required businesses to sign compliance agreements that mandated specific activities prior to and during harvest, transport, processing and waste handling. Compliance agreements were also required for similar activities in raisins and regulated fruit other than grape, including olive, persimmon, pomegranate, most stone fruit (Prunus spp.) and specific caneberries. Based on recommendations provided by the TWG, in 2012 the USDA revised the list of regulated articles to exempt olive fruit and Rubus spp., and limited the acreage of Prunus spp. affected.

\section{Management of winery waste}

The possibility that EGVM could survive in unfermented winery waste was addressed by requiring that waste be composted on site, transported to an approved compost facility or returned to the vineyard of origin, depending on where the fruit was sourced relative to the quarantine area and county. Alternatively, if grapes were pressed to a minimum of 2 bars ( $0.2 \mathrm{MPa})$ or $28 \mathrm{psi}$, then movement of waste was unrestricted within California. Investigations provided evidence that EGVM larvae could survive on unpressed green waste after destemming and determined that in general the processing equipment was likely a greater source of contamination than unfermented waste (Smith et al. 2013). Mature larvae may move from clusters to protected locations, emphasizing the need for thorough washing of all equipment used to harvest, transport and process infested loads of grapes.

\section{Outreach and educational program}

EGVM program leaders provided transparent, consistent, timely and coordinated communication to parties directly and indirectly affected by the EGVM program. USDA led international communications and jointly with CDFA coordinated statewide communication. County agricultural commissioners and UC advisors directed local communication and assisted in other efforts. The outreach program also collected relevant information from stakeholders to ensure the appropriateness of regulatory requirements and adapted the program to local conditions and concerns. This openness and flexibility to change fostered the development of trust, respect and cooperation among all parties. The proactive, local campaign to communicate, educate and collaborate with a diverse community became a hallmark of the EGVM program (Zalom et al. 2013).

Industry outreach and education. Many methods were used to communicate information to growers and winery personnel. Educational materials included two tri-fold brochures, a poster and training videos developed and distributed through UC Cooperative Extension. Mass marketing campaigns raised public awareness using postcards, door-hangers, magnets, billboards and campaign signs, public service announcements, and online and social media; cross-linked websites provided comprehensive and current
TABLE 7. Surveys of alternate host plants along the Napa River, 2010-2011

\begin{tabular}{lc}
\hline \hline Plant type & Number of fruit/flowers inspected \\
\hline Blackberry & 55,625 \\
Elderberry & 230,615 \\
Olive & 3,937 (and 4,837 leaves) \\
Wild rose & 2,962 \\
Wild or & 28,471 \\
domestic grape & \\
Wild or & 2,582 \\
domestic plum & \\
Peach & 83 \\
Nectarine & 83 \\
Walnut & 226 \\
Blueberry & 305 \\
Gooseberry & 342 \\
\hline
\end{tabular}

information. The online UC IPM Pest Alert presented information on pest identification, biology and management.

Grower liaison/outreach coordinators in Napa, Sonoma, Mendocino and Fresno counties played an important role in outreach and educational efforts. In each county, the EGVM grower liaison conducted targeted outreach and was a trusted, independent source of information for growers and winery personnel. Program information was communicated at meetings, seminars and field days, as well as through individual communications and a UC Cooperative Extension Napa County newsletter. Farmworkers particularly important "first responders" capable of identifying potential threats during their daily work - were reached through Spanish language presentations, field days and outreach materials. Partnerships with local industry groups 


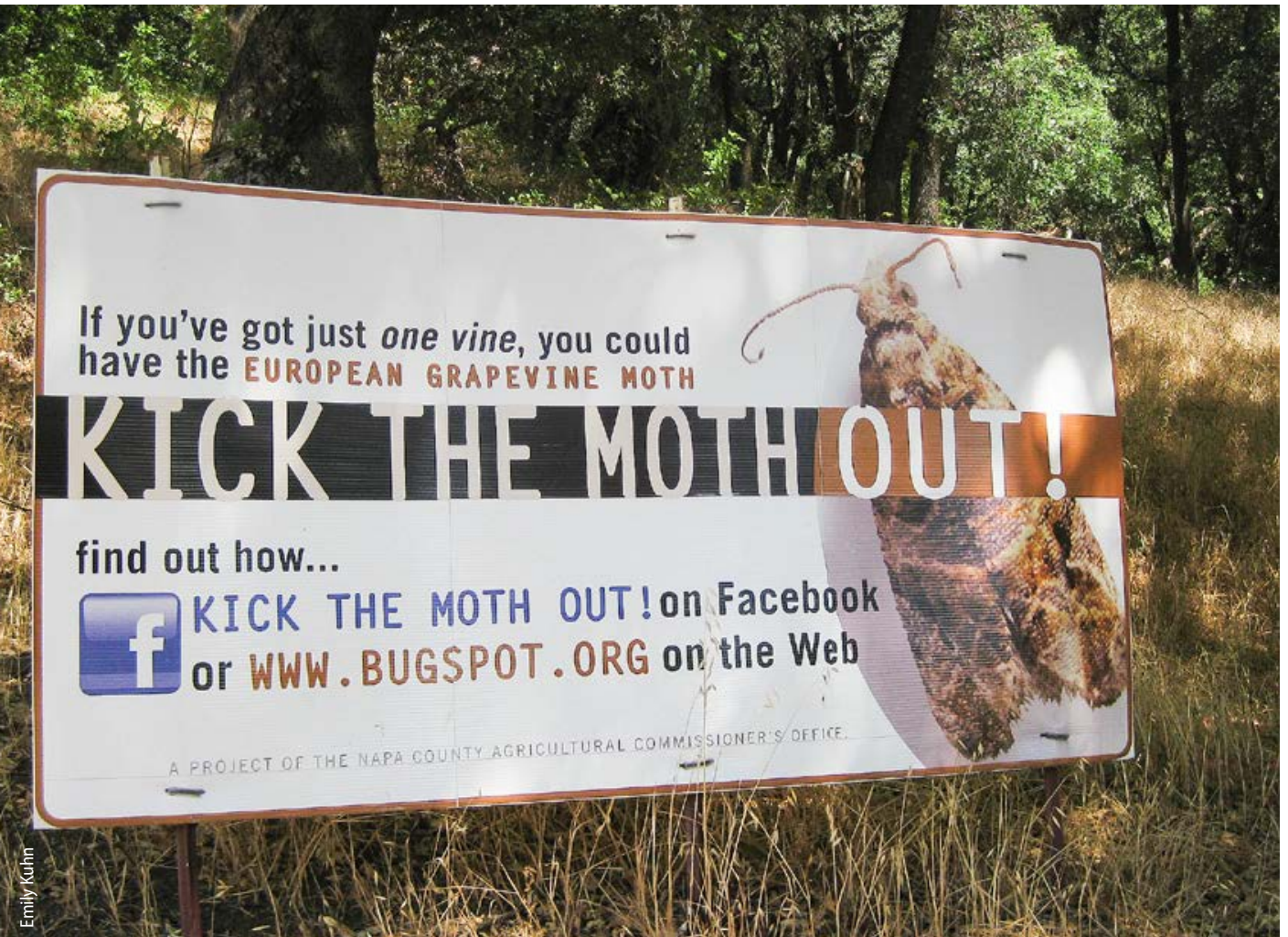

The public campaign "Kick the Moth Out" raised awareness of the EGVM program in Napa County.

to deliver program information contributed to the educational efforts. Growers also shared information and related their experiences through peer networks that strengthened the formal educational program.

Public outreach and education. An estimated 2.5 million acres of California farmland are adjacent or in close proximity to nonfarm residences (Hammond et al. 2010). To address potential areas of urban-agricultural conflict, county agricultural commissioners supported by USDA, CDFA, UC and industry groups worked within established local networks of community leaders to develop a public outreach campaign. County supervisors and city council members, environmental, community and commercial organizations, residents and tourists were the targets of the outreach efforts, which built trust between program and community leaders, growers and the public.

\section{Program update}

The conditions set forth by the TWG specified that in areas attempting to qualify for deregulation (1) no moths must be captured during five consecutive generations, (2) insecticide treatments must continue to target the first and second generation, (3) MD may not be used during the final two generations that the area is under regulation and (4) during these two generations, trap density must increase to 100 traps per square mile ( 39 traps per $\mathrm{km}^{2}$ ) (one trap per 6 acres) in all vineyards within 1,640 feet (500 m) of previous detections. Under California conditions, only the first and second are considered full generations because a proportion of the second generation enters diapause (L. Varela and M. Cooper, personal observation). Four counties (Fresno, Mendocino, Merced and San Joaquin) were removed from regulation at the beginning of 2012, and by the end of 2012, five additional counties (Nevada, Santa Clara, Santa Cruz, Solano and Sonoma) had been deregulated partially or in full.

Napa County and portions of neighboring Sonoma and Solano counties remained under regulation in 2013, an area encompassing 686 square miles (fig. 2). Due to the historically large and widely distributed populations in Napa County, the TWG recommended a revised approach to deregulation: High-density traps (100 per square mile) deployed county-wide must be free from detections during four full flights before areas will be considered for deregulation (Mastro et al. 2012). Any moth captured will trigger the delimitation and establishment of treatment areas within 1,640 feet (500 $\mathrm{m})$ of the detection. Consequently, trap density nearly tripled in Napa County in 2013 (table 1) and the area under MD shrank from 23,000 to 2,800 acres in 2013 and approximately 1,907 acres in 2014. The remaining EGVM population in Napa County has been drastically reduced in size and distribution (fig. 2; table 1).

By mid-August 2014, southern Sonoma County, the remainder of Solano County, and a portion of southern Napa County were removed from quarantine. The remainder of Napa County and a portion of northern Sonoma County, an area totaling 446 square miles, will continue to be regulated in 2015. Pheromone-baited trap surveys continue in other grape-growing areas of California and the United States as part of CDFA/USDA early detection programs. These surveys detected one moth in Sonoma County in 2014; this was not sufficient to trigger establishment of a new quarantine boundary.

\section{A model collaborative effort}

Development and implementation of a successful regulatory program in response to the detection of an invasive species in California agricultural systems requires a concerted and coordinated effort to address the pest while balancing the needs of the agricultural industry, trading partners and the general public. Regulatory, fiscal, environmental and biological aspects must be weighed to develop goals and determine program activities. The leaders of the California EGVM program were sensitive to these issues and gained credibility and trust by involving a diverse community for dialogue, responding to the needs of local communities, considering the impact on the environment, adopting new scientific information, investing in relationships and networks, and ensuring the appropriateness of regulatory requirements (Zalom et al. 2013). Factors such as the insect's limited host range, which allowed the program to focus on commercial vineyards; the use of management tools that minimized the impact to nontarget organisms and are compatible with organic and backyard vineyards; and the long history of EGVM management in the Palearctic region also contributed to the successes of the program. The EGVM program 
leaders were recognized with the USDA Administrator's Award in September 2012, acknowledging the program's successful collaborative approach. The program has clear direction and well-defined goals, is grounded in biology, engages a diverse community and is responsive to the changing needs of participants. The participation of USDA, CDFA, agricultural commissioners, UC and other university scientists, growers, industry groups, community leaders and the general public resulted in a model effort that has reduced EGVM populations to a few areas of Napa and Sonoma counties. CA

M. Cooper is UC Cooperative Extension (UCCE) Farm Advisor-Viticulture, Napa County; L. Varela is UCCE IPM Advisor-North Coast; R. Smith is UCCE Farm Advisor-Viticulture, Sonoma County; D. Whitmer is Agricultural Commissioner and Sealer of Weights \& Measures (Retired), Napa County; G. Simmons is CPHST Supervisory Agriculturist, USDA, APHIS, PPQ; A. Lucchi is Professor, University of Pisa, Italy; R. Broadway is GIS Specialist, USDA, APHIS, PPQ; and R. Steinhauer is Wine Grape Grower, Wineland Consulting, Napa, CA.

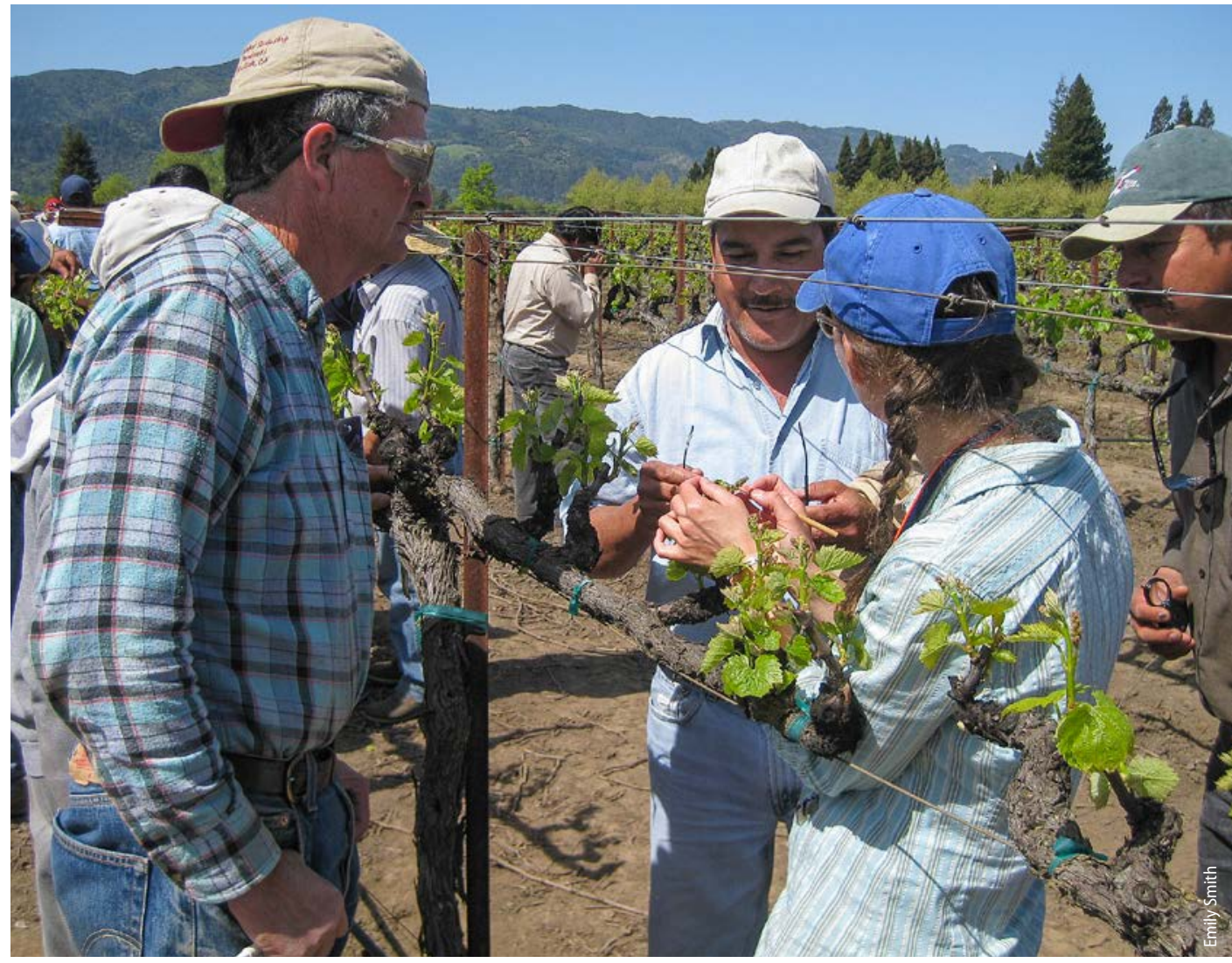

Field day training sessions with growers and farmworkers were held in Oakville, CA, in April 2010.

\section{References}

Boller EF. 1993. Wie weit fliegt der Traubenwickler? Deut Winbau Jahrbuch 44, Waldkircher Verlag, Waldkirch, Germany.

Caffarelli V, Vita G. 1988. Heat accumulation for timing grapevine moth control measures. Bulletin SROP 11:24-6.

[CDFA] California Department of Food and Agriculture. 2012. European grapevine moth (Lobesia botrana) state interior quarantine. In: California Department of Food and Agriculture Plant Quarantine Manual 3437:422.1-12 http://pi.cdfa.ca.gov/pqm/manual/pdf/422.pdf.

Gutierrez AP, Ponti L, Cooper ML, et al. 2012. Prospective analysis of the invasive potential of the European grapevine moth Lobesia botrana (Den. \& Schiff.) in California. Agr Forest Entomol 14:225-38

Hammond SV, Norton MV, Schmidt EE, Sokolow A. 2010. California communities deal with conflict and adjustment at the urban-agricultural edge. Calif Agr 64:121-8. doi: 10.3733/ca.v064n03p121.

loriatti C, Anfora G, Tasin M, et al. 2011. Chemical ecology and management of Lobesia botrana (Lepidoptera: Tortricidae). J Econ Entomol 104:1125-37.

loriatti C, Bagnoli B, Lucchi A, et al. 2004. Vine moths control by mating disruption in Italy: Results and future prospects. REDIA 87:117-28.

Ioriatti C, Lucchi A, Varela LG. 2012. Grape berry moths in western European vineyards and their recent movement into the New World. In: Bostanian NJ, Vincent C, Isaacs R (eds.). Arthropod Management in Vineyards: Pests, Approaches, and Future Directions. Springer Science + Business Media B.V. p 339-59. doi: 10.1007/978-94-0074032-7_14.
Lucchi A, Bagnoli B, Cooper M, et al. 2012. The successful use of sex pheromones to monitor and disrupt mating of Lobesia botrana in California. Working group meeting on pheromones and other semio-chemicals in integrated production, October 1-5, 2012, Bursa, Turkey. IOBC-WPRS Bulletin 99:45-8.

Lucchi A, Santini L. 2011. Life history of Lobesia botrana on Daphne gnidium in a natural park of Tuscany. IOBCWPRS Bulletin 67:197-202.

Maher N. 2002. Oviposition site selection by Lobesia botrana (Lepidoptera: Tortricidae): Influence of non- volatile chemical cues from host plants fruits [in French]. PhD thesis, Université de Bordeaux 2, France. 109 p.

Mastro V, Cardé R, Cooper M, et al. 2012. Report of the Technical Working Group for the European Grapevine Moth Program in California. October 30-November 1, 2012, Sacramento, CA. www.aphis.usda.gov/plant health/plant_pest_info/eg_moth/downloads/TWGReport-Dec2012.pdf.

Mastro V, Cardé R, Lance D, et al. 2010. Second Report of the USDA International Technical Working Group for the European Grapevine Moth in California. May 14, 2010. www.aphis.usda.gov/plant_health/plant_pest_info/ eg_moth/downloads/TWG\%20report-5-14-2010.pdf. Pasquier D, Charmillot PJ. 2005. Survey of pheromone emission from different kinds of dispensers used for mating disruption in orchards and vineyards. IOBC-WPRS Bulletin 28:335-40.

Schmitz V, Roehrich R, Stockel J. 1996. Dispersal of marked and released adults of Lobesia botrana in an isolated vineyard and the effect of synthetic sex pheromone on moth movements. J Int Sci Vigne Vin 30:67-72.
Smith RJ, Cooper ML, Varela LG. 2013. Determining the threat of dispersal of Lobesia botrana larvae in infested grapes processed for winemaking. Practical Winery and Vineyard August 2013:73.

Torres-Vila LM, Rodríguez-Molina MC, Stockel J. 2002. Delayed mating reduces reproductive output of female European grapevine moth, Lobesia botrana (Lepidoptera: Tortricidae). B Entomol Res 92:241-9.

Touzeau J. 1981. Modelisation de l'evolution de l'Eudémis de la vigne pour la région Midi-Pyrenées. Bol Zool Agr Bach II 16:26-8.

USDA. US Department of Agriculture. 2010. Establishment of Quarantine Areas in California for European Grapevine Moth, Lobesia botrana. APHIS Federal Do mestic Quarantine Order DA-2010-25, June 22, 2010.6 p. www.aphis.usda.gov/plant_health/plant_pest_info/ eg_moth/downloads/spro/DA-2010-25.pdf.

Van Steenwyk RA, Varela LG, Cooper ML. 2011. Monitoring and control of European grapevine moth, Lobesia botrana (Lepidoptera: Tortricidae) in California vineyards. Abstracts of the IOBC-WRPS meeting in Lacanau, France. October 2-5, 2011

Varela LG, Cooper ML, Smith RJ. 2013a. Can European grapevine moth, Lobesia botrana (Lepidoptera: Tortricidae) be eradicated from California? In: Calonnec A, Duso C, Gessler C, et al. (eds.). IOBC/WPRS Bulletin 85:92-102.

Varela LG, Cooper ML, Smith RJ. 2013b. Trapping for European grapevine moth. CAPCA Adviser 16:20-5.

Zalom F, Grieshop J, Lelea M, et al. 2013. Community Perceptions of Emergency Responses to Invasive Species in California: Case Studies of the Light Brown Apple Moth and the European Grapevine Moth. Report submitted to USDA in fulfillment of Cooperative Agreement \#10-8100$1531-C A$ 